\title{
Local government and community events in New Zealand: a case study of two neighbouring cities
}

\section{Commonwealth Journal of Local Governance \\ Issue 21: December 2018 \\ https://cjlg.epress.lib.uts.edu.au}

\author{
Joany Grima \\ School of Business \\ Wellington Institute of Technology \\ Wellington 5012 \\ New Zealand \\ Email: joany.grima@weltec.ac.nz
}

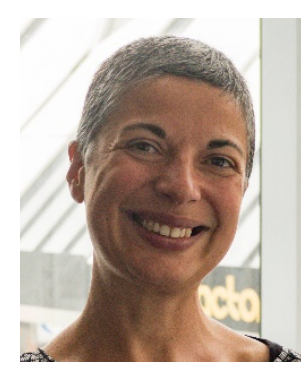

\begin{abstract}
The objectives for this research project were to examine the quality and type of support offered to community events through a case study of two neighbouring councils in the North Island of New Zealand; and to determine the impacts of events staged in the communities of both councils, including their influence on social capital building.
\end{abstract}

The study found that both councils are supportive of the delivery of events by both council and noncouncil event organisers. The councils are providing human, financial and physical capital to enable the output of events. Event impacts - specifically social and economic impacts - were considered to be positive in nature.

However, there is scope for greater strategic planning around community event delivery both by individual authorities and collaboratively, including the establishment of formal monitoring and evaluation systems. There is also scope to incorporate key lessons in regard to good practice, as identified by this study.

\section{Introduction and objectives}

Community events such as festivals, fairs and sporting events are frequently staged in cities and towns across New Zealand. Local councils play a key role in ensuring community events are organised, supported and facilitated, be it through providing venues, funding, advice or access to resources; or by taking on event management responsibilities to deliver a publicly accessible event.

Local governments are known to develop event strategies that include a portfolio of events (O'Toole 2011), ranging in scope and scale. In New Zealand, local councils embed community events in their

DOI: https://doi.org/10.5130/cjlg.v0i21.6518

Article History: Received 01/04/16; Accepted 04/05/18; Published 01/04/2019

Citation: Commonwealth Journal of Local Governance 2018, 21: 6518, https://doi.org/10.5130/cjlg.v0i21.6518

(c) 2019 Joany Grima. This is an Open Access article distributed under the terms of the Creative Commons Attribution 4.0 Unported (CC BY 4.0) License (https://creativecommons.org/licenses/by/4.0/), allowing third parties to copy and redistribute the material in any medium or format and to remix, transform, and build upon the material for any purpose, even commercially, provided the original work is properly cited and states its license. 
day-to-day operations. However, there are variations between councils as to the input and investment made in community events, which this research project aims to explore through a case study methodology comparing two neighbouring councils.

The objectives for this research project were to determine 1) the support offered to community events by neighbouring councils; and 2) the impacts of events staged on the communities of the two councils, including their influence on social capital building. ${ }^{1}$

\section{Methodology \\ The research setting}

Councils A and B are neighbouring local governments in the North Island of New Zealand. Council A possesses greater land mass, featuring large areas zoned as rural, while council B has a larger population and number of dwellings. Both councils are cities by definition. Council A has no events strategy, while council B follows a 10-year events strategy. Events feature prominently on both council websites, and are mentioned in their long-term plans. Council B's events output outweighs that of council A, with council B initiating, planning and delivering a number of regular 'showcase' and 'premier' events (as defined in its events strategy). Both councils attract a wide range of events organised from outside council, particularly outdoor sporting events.

Information available to event organisers delivering events within each city varies. Council A provides detailed online information and resources to facilitate running an event. These include advice on event promotion, booking council venues, using council noticeboards, road closures, food and liquor licensing, permits and waste management. Council B also provides useful online information relating to funding opportunities and event logistics, though in less detail than council A. It further describes its events role in a number of ways: as an owner and provider of venues and public spaces; as a direct supplier that initiates, plans and delivers events; as a facilitator, supporting events by playing a regulatory and advisory role; as a funder and champion of events; and as a promoter of events.

Both councils provide a contestable pool of funds for event organisers to apply for, funded through the respective event operating budgets. Council A has a total annual events fund of $\$ 50,000$ for council and non-council events, while council B has an annual support fund dedicated to non-council events of $\$ 100,000$, and a contestable fund of $\$ 150,000$. Both councils also make a wide variety of non-financial resources available to events, such as venues, equipment, signage, promotion and informal advice enabling organisers to navigate council processes and meet regulatory obligations.

\footnotetext{
${ }^{1}$ This paper is based on 'A tale of two cities: local government, community events and social capital building', a Master's degree thesis completed by the author in 2016 (Grima 2016).
} 


\section{Participants}

Participants in this research fell into three categories: key council personnel involved in events; local councillors with a strong interest in community events; and local event organisers collaborating with council in some way to deliver events. To preserve anonymity, participants are referred to as 'council A event organiser' and 'council B event organiser'; 'councillor A' and 'councillor B'; and 'non-council event organiser A' and 'non-council event organiser B'. A total of six participants were recruited, all of whom lived and worked within the council boundaries they were selected to be questioned on.

To achieve a triangulated overview of how councils A and B support and approach the delivery of events, semi-structured, face-to-face interviews were undertaken with participants over a two-month period in 2015. The questions were designed to collect data on: the support for events available from each council, such as funding, venues, human resources and marketing platforms; the strategic objectives rationalising council support for events, such as 'pride in place', community building and well-being, economic growth and the attraction of visitors; and event impacts, including social capital building through events. A qualitative approach was chosen as it allowed for more comprehensive and robust responses than would be achieved by a quantitative study. Also, the investigation of the same research questions in two or more places using a common method facilitates comparative research (Nicholson and Pearce 2001).

The methodology was inspired by that employed by Pugh and Wood (2004) in their research project titled The strategic use of events within local government: A study of London borough councils. Pugh and Wood's research builds on work previously undertaken by Bennett and Koudelova (2001) on improving the image of downtown areas in London and New York, which recommended a more strategic approach to marketing by councils. Pugh and Wood (2004) attempted to ascertain whether events were being used strategically and complementary to statutory services such as regeneration and social welfare and as part of an integrated plan, or as a marketing tool by London borough councils, using face-to-face interviews supplemented by the analysis of relevant council documentation.

\section{Literature review}

\section{The role and impacts of events}

Events play an important role in society, breaking up the routine of daily life (Shone and Parry 2013); and are delivered in specific social, political, economic and environmental contexts with the ability to significantly impact the host community (Holmes et al. 2015; Arcodia and Whitford 2006). The impacts of events, both positive and negative, are becoming more detailed and better known as research knowledge expands.

Festivals and community events evolve from, and mirror the values of, the communities which create them (Getz and Frisby 1988). Although they display considerable variation, festivals and community 
events are always about people - those producing them, and those attending them (Buch et al. 2011). Events are important for their social and cultural roles, with public and not-for-profit sectors being the most frequent event hosts (Andersson and Getz 2008). Usually held annually or biennially, festivals and community events generally enjoy the ongoing support of the local council they operate within, target audiences who are primarily local (Small et al. 2005), and are organised cooperatively by volunteers with support from local organisations, the local business community, and the local council (Allen et al. 2011).

Public agencies with responsibilities for well-being outcomes are increasingly realising that festivals and community events are a powerful tool for engaging effectively with communities (Phipps and Slater 2010). By their communal nature, events help to build and strengthen community ties; they also develop local infrastructure and provide spending channels for residents and visitors (Pegg and Patterson 2010). Festivals have the ability to shape a community's image (Delamere 2001); play an important networking role (Pickernell et al. 2007); provide a centre of orientation for a community (Yuen and Glover 2005); and place or keep towns 'on the map' (Brennan-Horley et al. 2007). Events are often seen as high points in the community calendar, building on and adding to a community's sense of place. Events also provide an avenue for communities to host visitors and share activities representative of community values, while outwardly manifesting community identity (Derrett 2005).

Event impacts are outcomes from the planning and delivery of the event - some of which are beyond the control of event organisers - whether or not they were expected to occur (Wood 2009). Event impacts can be both direct and indirect, and have the potential to permeate the host community; for this reason, the study of social impacts in particular is an important aspect of event management (Mackeller 2013). Social impacts are defined as anything potentially having an effect on the quality of life for the host community (Fredline et al. 2003). In order to constructively manage event impacts, event organisers should continually be aware of community interests and concerns (Small 2007). Often, the positive social impact on the host community is why event organisers become involved to begin with (Finkel 2010); therefore, awareness of impacts and of host community attitudes toward those impacts is beneficial for event organisers seeking to maximise social benefits and minimise social costs (Delamere 2001).

Events have been credited with the building of social capital in a community (Jamieson 2014; Reid 2007; Yuen and Glover 2005). The Organisation for Economic Co-operation and Development defines social capital as "networks together with shared norms, values and understandings that facilitate cooperation within or among groups" (Keeley 2007, p.103). Indicators of social capital include levels of giving, civic engagement, voluntary activity, participation, meeting obligations, community reciprocity and trust - including trust in public institutions such as local government (Spellerberg 2001). 


\section{Event strategy}

Event strategy refers to developing a long-term plan of action to achieve organisation-wide objectives through the design, implementation and evaluation of events (O'Toole 2011). Governments at all levels play a role in employing and developing event strategies, consciously using events in tandem with other policies and strategies to achieve short- and long-term goals (Allen et al. 2011). Existing research (O'Toole 2011) suggests that local governments strategically support events for four broad reasons: strengthening the community, event sustainability, economic development, and to increase tourism to the area. It has also been suggested that strategic event planners should not hesitate to discontinue events that do not meet their objectives, as an effective portfolio of events is of utmost importance (Getz 2002). Local governments develop strategies that span a range of events, in order to coordinate and facilitate their involvement, and make effective use of resources (O'Toole 2011). Event portfolios may include both existing events known to the host community and newly-sourced events, while an event strategy may include providing resources to event organisers to assist with event planning and delivery (Allen et al. 2011).

In their research into the strategic use of events by London borough councils, Pugh and Wood (2004) found that event strategies developed by local councils were more successful if they featured clear objectives that complemented broader strategies for the area, and also if they were allowed time to develop and produce long-term results. In recent decades, incorporating festivals and events into city planning has become a recognised strategy to further local urban and economic development, and to positively promote the image of a city (Jakob 2013). This builds on the work of Wood (2006), who suggested that non-strategic use of events by local government is a missed opportunity to gather information on the effectiveness of their events, including positive social impacts such as community building, making it difficult to justify delivering a portfolio of events.

Local government is an important player in the delivery of events, as consent from the local council is often a prerequisite for an event to be staged (Larson 2002). The local council is a regulator, and sometimes also a facilitator and partner (Getz et al. 2007), with a leading role to play in supporting the sustainable operation of local events (Jones 2014). Derrett (2005) outlines the stakeholder role of local government as encompassing policy and planning frameworks, events and project management personnel, infrastructure support, and in-kind and financial investment. Events supported by local government can encourage a positive attitude to the local council by its constituents (Wood 2009).

The literature on the role and impact of events and event strategy is largely in support of community events, particularly the ongoing involvement of local councils. This research project seeks to add to the body of knowledge from a New Zealand perspective, and apply learning from the international literature to a local context. 


\section{Findings}

The findings are presented in sections aligning with the interview question themes, with responses from councillors A and B, council event organisers A and B, and non-council event organisers A and $\mathrm{B}$. In common among the six participants was their commitment to delivering quality community events; as well as a personal belief in the positive impact of community events. Each participant had dedicated a significant amount of their work history to event management, as well as volunteering free time to 'give back' to the community through the staging of events.

\section{Support and resources for events}

All respondents agreed that their respective councils provide support and resources for non-council events. Overall, however, there was a feeling that councils could be doing more, but that input was limited. Reasons given for this were lack of funding and lack of council staff interest.

The two councillors interviewed were positive about council support for non-council events. Councillor A felt the council had a good approach to managing local venues and noted that most events were provided either free of charge or at very low cost. The potential for events to have an economic impact in the area was part of the council rationale for this support. Council event organisers were seen as an intermediary to help community events be delivered, connecting event organisers with the people required to enable their events and were able to "give good advice and try to be a one-stop-shop". Councillor B felt that the council "provides quite a lot of support", despite the demanding workload and limited financial capacity, and was "convinced that if a group wanted to put something on and they needed assistance in knowing how to project manage or plan... the council officers would probably be quite supportive”.

Council A event organiser felt council staff in general were approachable and easy to connect with. Council venues were offered free of charge or at discounted rates for community events "to make things more accessible". Staff work closely with non-council event organisers, "and if it's something that I'm really passionate about, I'll work for free". Council A event organiser was mindful of the need to cover costs and continue to be a viable council operation, although noting that "nothing's ever a no, we will always try and make something happen".

Council B event organiser, somewhat in contrast, believed contact with non-council event organisers could be increased. Apart from delivering the council events portfolio, council B event organiser spent the majority of their work time managing a contestable fund for event organisers. As part of its events strategy, council B was planning to create event management guidelines for event organisers as a "how to" approach to simplify staging events in the area, as well as delivering training workshops on best practice event management in the near future to strengthen the skills of local event organisers. 
Networking sessions were also planned, in order for event organisers to connect and potentially collaborate.

Non-council event organiser A has extensive experience of working with council A, through a longstanding arrangement for the complimentary use of a council-operated park to deliver a biennial event. However, this respondent felt that although council staff are supportive of events, "they're not passionate about the city or about events", and was disappointed to not have "seen a council person at any of our events". The support of the council was considered a strong influencing factor in the sustainability and long-term existence of the event, particularly in the wake of staff changes which had affected liaison with non-council event organisers: "It's definitely harder to run an event now than it was".

Non-council event organiser A suggested the council could facilitate a biannual meeting of local event organisers in order to network, coordinate an events calendar, and share resources, knowledge and skills. Council assistance within such a forum with risk management compliance, health and safety and traffic management would also be well received. This respondent also appreciated the fact that the council provided a valuable event promotion tool via its website, and also had arrangements with broadcasters and advertisers available to non-council event organisers.

Non-council event organiser B acknowledged that their council provided advice and opportunities for funding, promotional support, venues and other resources to non-council event organisers, but was disappointed by what they saw as onerous conditions applied to a small amount of funding secured for the delivery of an event. The funding process was considered "quite time-consuming; not very userfriendly and wasn't really helping me much". However, like their counterpart in council A, this respondent felt that event promotion was done quite effectively and simply via the council website.

\section{Event strategy}

Councillor A described strategic event objectives as being connected to creating a vibrant central business district, and generating economic benefits for local retailers. Engagement with youth and providing a place of activity were also cited as objectives, as well as staging events to act as a destination attraction for people from within and outside the city. Councillor A was aware that some councils have adopted event strategies and policies, but that council A had not opted to do so. Instead, councillor A felt the council portfolio of events, and the events it offered support to, was driven largely by the existing infrastructure in the city, specifically its venues and the natural environment.

By contrast, in regard to strategic event objectives councillor B felt that council-run events are very much about creating community involvement and connectedness. "You need to have your community involved and feeling connected with the area they're in so that you can actually run a city. If everybody doesn't care about where they live, you don't get very far." Councillor B believed that events helped 
foster community feeling, and creating events that involve and engage family groups to "get some sort of impetus and input is very important". While councils have a responsibility to provide basic services such as rubbish collection, councillor B believed that councils also played a role in nurturing the welfare of the community, a part of which was fulfilled by community events.

Although council B does have an events strategy, councillor B felt that an "instant gratification" approach to events often worked against the long-term success of events. Council B was inclined to drop events that were not drawing large crowds after several years, rather than progressively growing these events. Councillor B felt strongly that council "underestimates the worth of events", with events being "totally underfunded"; although acknowledging that funding had increased somewhat over the years. Councillor B also felt that when events personnel within council changed, so too did the events portfolio, but without a rationale to justify doing so. Despite these criticisms, however, councillor B considered the events staff "undervalued and underfunded".

When asked about how events were selected, "We do kind of everything" was council A event organiser's response. A change in management prior to data collection had influenced the communityoriented direction of the events, in particular to engage youth. "We're very conscious of our community and engaging them [youth]." Council A event organiser commenced event planning for the following calendar year during the last quarter of the current year. This planning is informal and internal, and not a strategic council requirement. Council A event organiser stressed that they consider non-council events when planning the events calendar. "We are very conscious when we are programming that we are catering for everybody and we're not clashing with other... community events that are going on."

Council B, on the other hand, works to a strategic events policy, with an expectation that events will fit into certain categories. Council B event organiser described the events strategy as aiming to achieve a portfolio of events covering different event types. The events strategy also sets the expectation that events will generate a return on investment in financial terms. Despite the existence of the events strategy, however, council B event organiser felt council B was at times reactive and ad hoc regarding its portfolio of council-delivered events. "We do [core events] around different areas of community and then we just try and fill in the rest of the year with as much as we can." Council B's events strategy fits within its overarching objective to make the area an attractive city to work, live and play. "People want to stay here, and live here because there are fun things happening for them to participate in and enjoy."

In an effort to deliver more strategic council events across the region, council B event organiser participates in a region-wide forum with other local council event organisers. The forum is still gaining traction and building trust, with the core idea being that events should complement rather than clash or compete with one another in different cities within the region. 
Non-council event organiser A was not aware of any council strategic objectives and was aware that their council did not have a formal events strategy. This was largely due to the fact that local event organisers were not consulted at any level regarding event output. "I don't think there's a grand strategic vision of where they're going with events." Non-council event organiser B, by contrast, felt that engaging with low socio-economic groups, ethnic minorities and women were part of the council's strategic objectives in relation to events; alongside providing recreation opportunities and meaningful engagement with youth. Non-council event organiser B suggested that council B focused disproportionately on the larger events it delivered, aiming to compete with bigger, neighbouring local councils.

\section{Impacts of events}

The impacts of events mentioned by participants were most closely aligned to economic and social impacts. Councillor A felt that the primary impact of events was the "feel-good factor" they could generate: among people coming into the area to attend the events, those living in the area who attend, and also non-attendees who "see that they're happening and get that impression of vibrancy". Economic benefits to local retailers were also mentioned, including opportunities for community group fundraising. Councillor B was less specific, but felt that events provided positive impacts that improved the community.

With respect to building social capital as an impact, councillor A commented this was "actually happening" within the community, particularly thanks to non-council event organisers who have "built really good relationships all around the community and with various parties, the council, other venues, other groups who have worked with them". Councillor B felt it was "absolutely imperative" that councils use their investment in community events to develop and fully maximise social capital gains that events can facilitate.

Council A event organiser felt that people can feel a "sense of belonging" by attending a community event, being part of the action rather than an observer. Council B event organiser was conscious of the social impacts that events could have in the community. "Events need to be accessible, you have to tailor them to a target audience. The community is very diverse so you need a diverse range of events." A focus for council B has been to stage affordable events so that those otherwise unable to afford such an experience are not excluded.

Both council event organisers made a connection between events and social capital building. However, council A event organiser pointed out that although events were capable of building social capital, "people don't always take advantage of the opportunities that are given to them by their communities" by participating in public events that could expand or strengthen their social network. Council B event organiser felt that "local governments have a need to be seen in a positive light regardless of how they 
achieve [social capital] through events". At times, this respondent felt council events took a 'top down' approach, rather than working with the community to determine their interest or otherwise in events. "It... has no thought for the area that they're doing it in. Is this event appropriate for the people that live in the area and is it something they even want?" Council B event organiser felt this approach to community events worked contrary to social capital building, as it was not conducive to trust-building between communities and their council.

Non-council event organiser A was more positive, feeling that event impacts included providing a showcase for the skills of community members, as well as "giving back to the community". Events offer an outlet to give "people an experience". Non-council event organiser B said events provided "people an opportunity to participate in something" while also attracting new people into the area. Community events were thought to be "a bit more personal", and many were about the participants "personally achieving" something from having partaken in a particular event, such as completing a fun run.

Both non-council event organisers mentioned that events had a positive economic impact on the community, including providing a forum for social capital building. Non-council event organiser A said: "There's probably several hundred people involved... in helping me put the event together" with each making a contribution to enlarging the social capital pool. Councils remaining autonomous rather than amalgamating was seen as an important way of ensuring social capital stores remain in the local community. At the time data collection occurred, a proposal to merge nine local authorities, including councils $\mathrm{A}$ and $\mathrm{B}$, was under consultation. This proposal has since been scrapped due to a lack of support.

\section{Discussion and conclusion}

The discussion is presented in sections aligning with the findings themes, concluding with a comparison of the councils' support for community events, and key lessons for local government.

\section{Support and resources for events}

There was agreement among respondents that councils A and B are approachable, helpful and supportive of event organisers, giving the impression of positive stakeholder relations. Good relationships with local councils are important for event organisers, particularly where financial support is being sought (Andersson and Getz 2008). Council event staff will generally do as much as they can to ensure events are successfully delivered. Where event organisers require guidance pertaining to event management, council staff are able to direct them to appropriate, freely accessible resources, as well as providing informal expertise and being a 'one-stop-shop'. Nevertheless, despite these resources noncouncil event organiser A still expressed a concern that "it's definitely harder to run an event now than it was". 
The tangible investment made by both councils in community events can be divided into three parts: money, resources and expertise. Although some respondents raised concerns regarding the funding available and the conditions surrounding grants, both councils do dedicate budgets to non-council events, and also provide access to in-kind resources. Council B event organiser gave the impression that applications for the contestable fund are highly competitive, although the non-council event organiser from the same council area felt that applying for funding could be considered too onerous where spending conditions are attached to the funding.

Council A provides online event management guidelines, while council B has no similar resources available. This could be indicative of council A's smaller events portfolio, and therefore its reliance on non-council event organisers to produce events for community consumption. However, council B does intend to produce guidelines for events organisers and, in time, deliver training workshops and host networking events; but these initiatives are still at the planning stage. The literature does identify such activities as part of the role of local government in supporting community events (Derrett 2005). A combined council A and council B annual forum of local event organisers could be a long-term goal of these networking opportunities.

\section{Event strategy}

Implementing a strategy effectively requires access to sufficient funding and resources. All respondents made reference to funding for events being challenging or insufficient; however exactly how the councils allocated, monitored and evaluated funding for events on an annual basis was beyond scope and not discussed in the interviews.

Existing literature suggests that local governments strategically support events for four broad reasons: strengthening the community, maintaining event sustainability, boosting economic development and increasing tourism to the area (O'Toole 2011). However, the results of the present study connect most strongly to events being used to strengthen the community. One could therefore question whether councils A and B could be more strategic and utilise events to achieve objectives beyond social outcomes. It is possible that neither council fully appreciates the multitude of impacts and benefits a strategically implemented portfolio of events can bring to their city. Understanding the impact of events would enable both councils to justify putting further resources into event delivery.

Council A does not work to a strategic events document of any description, even though relevant academic literature suggests that non-strategic use of events by local councils makes it hard for them to gather information on the effectiveness of their events (Wood 2006). Neglecting to adopt an events strategy or to set objectives to underpin event outputs makes it difficult for council A to measure the success of the events in question, or to assess the value the associated taxpayer investment. Council A's 
event organiser did discuss strategic planning; however, this work was not aligned to any council-issued instruction or guidelines.

Although council B event outputs are guided by a broad events strategy, the document spans a ten-year period and will be outdated by the time it is due for renewal in 2023. Absent from the strategy are plans to regularly review, monitor or evaluate the strategy, or a list of the events it supports during its lifespan.

The comment from councillor B that councils should nurture the welfare of the community, which they did in part through community events, indicates that events are seen as just one aspect of a wider welfare role. Consideration could therefore be given to aligning any event strategies with other council strategy documents concerning community welfare projects funded and undertaken by council. The literature suggests that public agencies with responsibilities for welfare and well-being outcomes are increasingly realising that festivals, in particular, are a powerful tool for engaging effectively with communities (Phipps and Slater 2010).

In the case of both councils, the effectiveness of the event portfolio is not being measured in a structured and meaningful way. One could therefore argue that the councils make decisions to alter events based less on strategy or evidence than on emotion, instinct or economics. However, regardless of how strategic or otherwise either council's approach to events is, both are supportive of the delivery of a range of non-council events. As council resources are limited, one could see this as a strategic approach, since failure to support these community events would lead to a large gap in each council's events calendar.

\section{Impact of events}

Participants in this project identified event impacts as being only positive in nature, which is potentially due to their interest and commitment to community events, despite events being known to have both positive and negative impacts. These event impacts were seen as both economic and social. Economic impacts were cited as local retailers and business owners benefiting from events taking place through audience spending. The social impacts identified by participants match those described in the literature. They included positive social interaction, community cohesion development and improving the community's identity and confidence (Shone and Parry 2013); and encouraging participation and strengthening community connections (Finkel 2010).

All participants in this study were interested in the social returns that events could provide. Yet, although social impacts were considered paramount, no social impact measures appear to be in place to fully assess social impacts - whether from the event organiser, event audience or host community perspectives. While events supported by the councils were generally credited with helping social capital to be built within the community, it seems likely that more could be done to enable this to take place. The suggestion, from non-council event organiser A, for a biannual meeting between event organisers 
and local event managers and council counterparts could further strengthen existing networks and build new connections. This could also work for council B, which intends to commence holding regular networking opportunities for event organisers, including training.

Trust is the basis of social capital building and maintenance (Keeley, 2007), an issue highlighted by council B event organiser, who was concerned that the 'top down' approach taken by council B regarding developing and implementing a portfolio of events without community consultation is not conducive to social capital building or to positive relations between council and community. Although the scope of event impacts on host communities is widely covered by the literature (Holmes et al. 2015; Pegg and Patterson 2010; Pugh and Wood 2004; Delamere 2001), event impacts do not appear to be fully understood, measured or evaluated by either council.

\section{Comparison of councils' support for community events}

Both councils provide similar resources in order to plan, deliver and support community events; the main difference in this area being the amount of dedicated funding for events. Council B leads on event strategy, funding, developing new resources for event organisers and its plans to coordinate specific networking and training opportunities for them; however, it lacks online event management resources such as those available from council A. Table 1 compares the two councils' approach:

Table 1: Comparison of Council A and Council B's support for community events

\begin{tabular}{|l|c|c|}
\hline Aspect/element & Council A & Council B \\
\hline Strategic events plan (current) & $\sqrt{ }$ \\
\hline Annual portfolio of events (council-staged) & $\sqrt{ }$ & $\sqrt{ }$ \\
\hline Contestable events fund & $\sqrt{ }$ \\
\hline Council-employed dedicated event staff & $\sqrt{ }$ & $\sqrt{ }$ \\
\hline Event management advice & $X$ & $\sqrt{*}$ \\
\hline Event management guidelines & $\sqrt{ }$ \\
\hline Online event management resources & $\sqrt{ }$ \\
\hline Online event promotion tools & $X$ & $X^{* *}$ \\
\hline Networking events for event organisers & $X$ & $X^{* *}$ \\
\hline Training sessions for event organisers & $\sqrt{ }$ \\
\hline Venue hire & $\sqrt{ }$ & $\sqrt{ }$ \\
\hline Equipment loan & $\sqrt{ }$ & $\sqrt{ }$ \\
\hline Road closure advice & $\sqrt{ }$ & $\sqrt{ }$ \\
\hline Awareness of event impacts & $\mathrm{V}$ & $X$ \\
\hline Monitoring and evaluation of event impacts & & $\sqrt{ }$ \\
\hline Developing new or existing event infrastructure & & \\
\hline Note. *Drafted, not public **Plans to commence in the future & & \\
\hline
\end{tabular}




\section{Key lessons for local government}

The comparison of councils A and B highlights examples of resources that can be developed or made available by other local councils to support community events. Key lessons for local government regarding both good and poor practice as determined by the analysis of interviews, are presented in

Table 2.

Table 2: Key lessons for local government

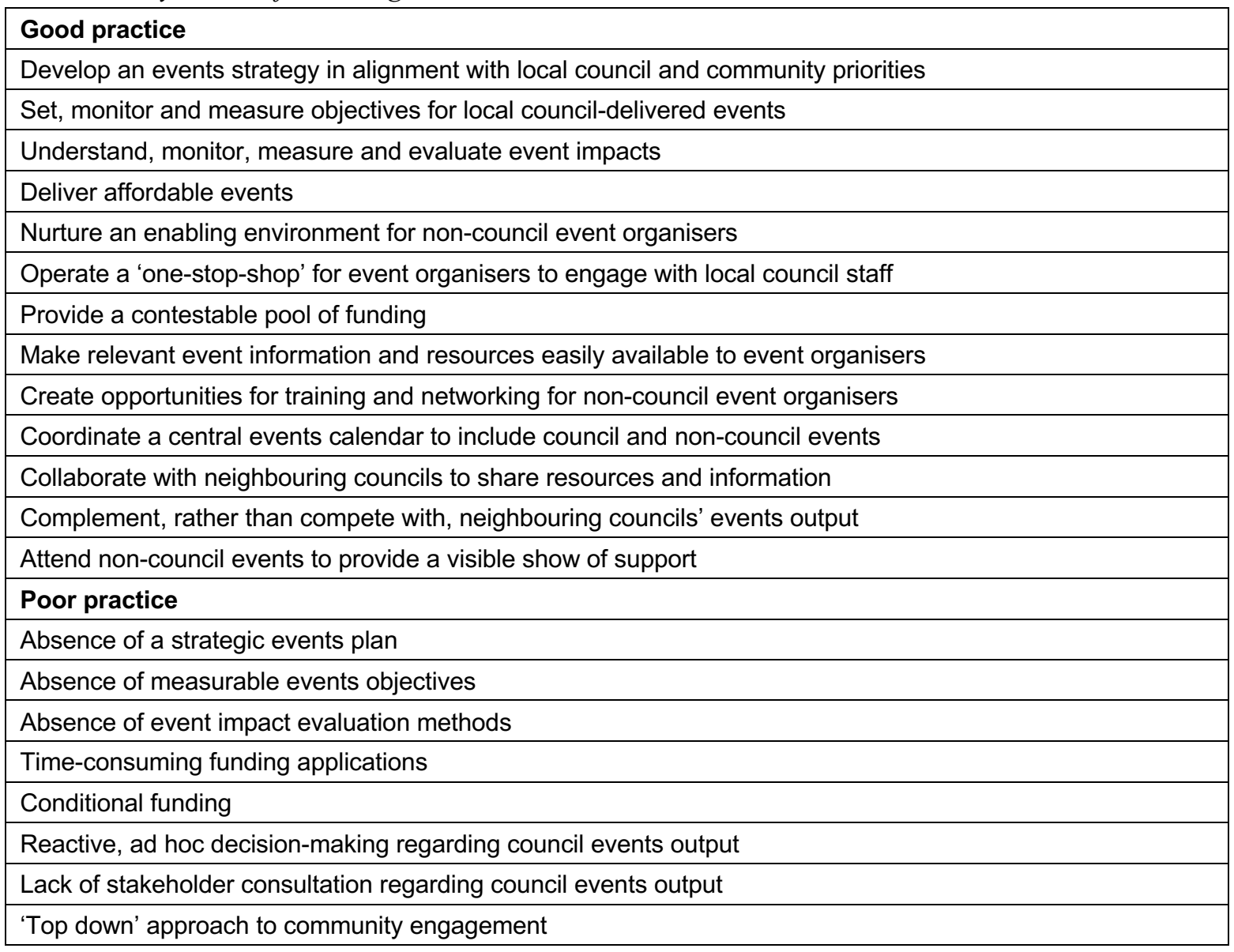

Events are beneficial to the community on many levels; therefore, a supportive, strategic and nurturing approach to staging events that adheres to good practice is recommended for local councils. An events strategy that is informed not just by the local council, but by the community and non-council event managers, is the foundation on which an effective portfolio of events can be built. Any strategy, however, should be coupled with measurable objectives and monitored impacts, and supported by a range of relevant event management resources, including easily accessible funding, information, training, networking and a central events calendar. The benefits of events to the community can be costeffectively extended by collaborating with neighbouring councils to share resources and deliver complementary events.

A poor practice approach by local council to events limits the documented social and economic benefits events can have in the community. Rather than be known as an events facilitator, supporter, champion 
and promoter, a local council may be perceived as a barrier to the delivery of an effective portfolio of council and non-council events. An absence of a strategic events plan supported by measurable objectives, lack of community consultation, and a 'top down' approach to community engagement works against events being effective in delivering positive community outcomes. A poor practice environment which non-council event organisers must negotiate may also ultimately result in a smaller number of delivered events, thus further diminishing the benefits of events to the community, and to local councils.

This research project has investigated the approaches to supporting the staging of community events, management strategies, and availability of event management resources within two neighbouring local councils. The perceived impacts of events on the host community, including social capital building, has also been explored, and key lessons for local government identified. Further study could investigate the impacts of events from the perspective of the host community and event attendees.

\section{Declaration of conflicting interest}

The author declared no potential conflicts of interest with respect to the research, authorship, and/or publication of this article.

\section{Funding}

The author received no financial support for the research, authorship, and/or publication of this article.

\section{References}

Allen, J., O’Toole, W., Harris, R. and McDonnell, I. (2011) Festival and special event management. (5th ed.) Milton: John Wiley \& Sons.

Andersson, T.D. and Getz, D. (2008) Stakeholder management strategies of festivals. Journal of Convention \& Event Tourism, 9 (3), 199-220. https://doi.org/10.1080/15470140802323801

Arcodia, C. and Whitford, M. (2006) Festival attendance and the development of social capital. Journal of Convention \& Event Tourism, 8 (2), 1-17. https://doi.org/10.1300/J452v08n02_01

Bennett, R. and Koudelova, R. (2001) Image selection and the marketing of downtown areas in London and New York. International Journal of Public Sector Management, 14 (3), 205-220. https://doi.org/10.1108/09513550110390855

Brennan-Horley, C., Connell, J. and Gibson, C. (2007) The Parkes Elvis revival festival: Economic development and contested place identities in rural Australia. Geographical Research, 45 (1), 71-84. https://doi.org/10.1111/j.1745-5871.2007.00429.x

Buch, T., Milne, S. and Dickson, G. (2011) Multiple stakeholder perspectives on cultural events: Auckland's Pasifika Festival. Journal of Hospitality Marketing \& Management, 20 (3-4), 311-328. https://doi.org/10.1080/19368623.2011.562416

Delamere, T.A. (2001) Development of a scale to measure resident attitudes toward the social impacts of community festivals, part II: Verification of the scale. Event Management, 7 (1), 25-38. https://doi.org/10.3727/152599501108751452

Derrett, R. (2005) Why do regional community cultural festivals survive? In: Allen, J. (ed.) The impacts of events conference proceedings (pp. 443-463). Sydney: University of Technology Sydney. 
Finkel, R. (2010) 'Dancing around the ring of fire': Social capital, tourism resistance, and gender dichotomies at Up Helly Aa in Lerwick, Shetland. Event Management, 14 (4), 275-285. https://doi.org/10.3727/152599510X12901814778023

Fredline, L., Jago, L. and Deery, M. (2003) The development of a generic scale to measure the social impact of events. Event Management, 8 (1), 23-37. https://doi.org/10.3727/152599503108751676

Getz, D. (2002) Why festivals fail. Event Management, 7 (4), 209-219. https://doi.org/10.3727/152599502108751604

Getz, D., Andersson, T. and Larson, M. (2007) Festival stakeholder roles: Concepts and case studies. Event Management, 10 (2), 103-122. https://doi.org/10.3727/152599507780676689

Getz, D. and Frisby, W. (1988) Evaluating management effectiveness in community-run festivals. Journal of Travel Research, 27, 22-27. https://doi.org/10.1177/004728758802700105

Grima, J. (2016) A tale of two cities: Local government, community events and social capital building. Master's degree thesis, Massey University, Wellington.

Holmes, K., Hughes, M., Mair, J. and Carlsen, J. (2015) Events and sustainability. London: Routledge.

Jakob, D. (2013) The eventification of place: Urban development and experience consumption in Berlin and New York City. European Urban and Regional Studies, 20 (4), 447-459. https://doi.org/10.1177/0969776412459860

Jamieson, N. (2014) Sport tourism events as community builders: How social capital helps the 'locals' cope. Journal of Convention \& Event Tourism, 15 (1), 57-68. https://doi.org/10.1080/15470148.2013.863719

Jones, M.L. (2014) Sustainable event management: A practical guide. New York: Routledge. https://doi.org/10.4324/9780203768723

Keeley, B. (2007) Human capital: How what you know shapes your life. (1st ed.) Paris, France: OECD Insights, OECD Publishing.

Larson, M. (2002) A political approach to relationship marketing: Case study of the Storsjoyran Festival. International Journal of Tourism Research, 4 (2), 119-143. https://doi.org/10.1002/jtr.366

Mackeller, J. (2013) World Rally Championship 2009: Assessing the community impacts on a rural town in Australia. Sport in Society, 16 (9), 1149-1163. https://doi.org/10.1080/17430437.2013.790893

Nicholson, R.E. and Pearce, D.G. (2001) Why do people attend events: A comparative analysis of visitor motivations at four South Island events. Journal of Travel Research, 39 (4), 449-460. https://doi.org/10.1177/004728750103900412

O’Toole, W. (2011) Events feasibility and development: From strategy to operations. Oxford: ButterworthHeinemann.

Pegg, S. and Patterson, I. (2010) Rethinking music festivals as a staged event: Gaining insights from understanding visitor motivations and the experiences they seek. Journal of Convention \& Event Tourism, 11 (2), 85-99. https://doi.org/10.1080/15470141003758035

Phipps, P. and Slater, L. (2010) Indigenous cultural festivals: Evaluating impact on community health and wellbeing. Melbourne, Australia: Globalism Research Centre, RMIT University.

Pickernell, D., O'Sullivan, D., Senyard, J.M. and Keast, R.L. (2007) Social capital and network building for enterprise in rural areas: Can festivals and special events contribute? In Proceedings of 30th Institute for Small Business and Entrepreneurship Conference (pp. 1-18).

Pugh, C. and Wood, E.H. (2004) The strategic use of events within local government: A study of London Borough councils. Event Management, 9 (1-2), 61-71. https://doi.org/10.3727/1525995042781093

Reid, S. (2007). Identifying social consequences of rural events. Event Management, 11 (1-2), 89-98. https://doi.org/10.3727/152599508783943192

Shone, A. and Parry, B. (2013) Successful event management: A practical handbook. Andover: Cengage Learning.

Small, K. (2007) Social dimensions of community festivals: An application of factor analysis in the development of the Social Impact Perception (SIP) scale. Event Management, 11 (1-2), 45-55. https://doi.org/10.3727/152599508783943219 
Small, K., Edwards, D. and Sheridan, L. (2005) A flexible framework for evaluating the socio-cultural impacts of a (small) festival. International Journal of Event Management Research, 1 (1), 66-77.

Spellerberg, A. (2001) Framework for the measurement of social capital in New Zealand. Wellington: Statistics New Zealand. Available at:

http://unpan1.un.org/intradoc/groups/public/documents/apcity/unpan011127.pdf [Accessed April 2015].

Wood, E.H. (2006) Measuring the social impacts of local authority events: A pilot study for a civic pride scale. International Journal of Nonprofit and Voluntary Sector Marketing, 11 (3), 165-179. https://doi.org/10.1002/nvsm.21

Wood, E. (2009) An impact evaluation framework: Local government community festivals. Event Management $12(3-4), 171-185$.

Yuen, F.C. and Glover, T.D. (2005) Enabling social capital development: An examination of the Festival of Neighborhoods in Kitchener, Ontario. Journal of Park and Recreation Administration, 23 (4), 20-38. 